\title{
The Origins of Bagan: New Dates and Old Inhabitants
}

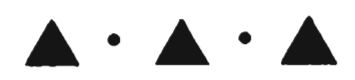

BOB HUDSON, NYEIN LWIN, AND WIN MAUNG (TANPAWADY)

Bagan, a name also commonly romanized as Pagan, ${ }^{1}$ is a historic urban center on the Ayeyarwady River in Upper Myanmar (East $94.875^{\circ}$, North $21.1666^{\circ}$; Map 2). ${ }^{2}$ Research into this important site has been in progress for a century. Regular reports or papers were published in the Archaeological Survey of India (ASI) 19021934, the Report of the Superintendent, Archaeological Survey of Burma (ASB) 19011965, and Journal of the Burma Research Society 1910-1980. Key reference works include Old Burma-Early Pagan (Luce 1969), Pagan (Aung-Thwin 1985), and The Inventory of Monuments at Pagan (Pichard 1992-1999). The city is a candidate for UNESCO World Heritage listing, a popular tourist and pilgrimage destination, and a symbol of national identity and aspiration. Its extant buildings effectively cover an area of $80 \mathrm{sq} \mathrm{km}$ (Hudson 1997).

Bagan's mainly brick monuments, erected for the glory of Buddhism and the spiritual advancement of those who sponsored the construction, are known through history and epigraphy to have been built largely between the eleventh and thirteenth centuries A.D. (Fig. 1). The Inventory of Monuments at Pagan (Pichard 1992-1999), a survey that followed a devastating earthquake in 1975, lists 2,237 temples, stupas, and monasteries in the eight volumes published or available at the time of writing. Several hundred more structures, mainly small mounds, are shown in the Inventory's end-paper maps, and await publication. Archaeologists at the site say forgotten ruins are still regularly unearthed in the Bagan archaeological zone. Even within "Old Bagan," the well-explored walled city core, visitors in January 2001 could see previously unrecorded building foundations being excavated by the Bagan Archaeology Department just south of pagodas 1636 and 1637. The authors have also identified or discovered several Bagan era sites or possible sites in the city's eastern hinterland, up to $20 \mathrm{~km}$ from the walled central complex (Hudson and Nyein Lwin 1999; Hudson et al. 2001).

Data used in this research has ranged from macro to micro: from satellite imagery, $1: 24,000$ and $1: 6,000$ aerial photographs, inch to the mile maps, and the extensive survey material from the Inventory of Monuments through to field survey

Bob Hudson is affiliated with the Archaeology Department, University of Sydney, Australia; Nyein Lwin is affiliated with the Department of Archaeology, Bagan; and Win Maung (Tanpawady) is a classical architect in Mandalay.

Asian Perspectives, Vol. 40, No. 1, (C) 2002 by University of Hawai'i Press. 
by jeep, bicycle, and foot, and the test excavation and sampling of the Otein Taung mounds (Fig. 3) for charcoal to use in radiocarbon dating. The research so far has suggested two possibly interrelated phenomena at Bagan: substantial settlement activity before the historically recorded medieval period ("medieval" in that it coincides historically with the era of the Crusades in Europe) and the long-term presence of the "Pyu," the iron-using, proto-Buddhist, ethnolinguistic group that called itself "Tircul" (Aung-Thwin 1994:18) and is identified with the settlements and culture of the Upper Burma dry zone in the first millennium A.D. (Aung Thaw 1968; Myint Aung 1970; Sein Maung 1981; Stargardt 1990).

\section{DATES DERIVED FROM DOCUMENTARY EVIDENCE}

The history and dating of Bagan before the epigraphic evidence of temple foundation stones becomes available is problematic. A rigorous interpretation of the founding date of A.D. 107 given in the Glass Palace Chronicle (Pe Maung Tin and Luce 1923) would be that this date is entirely mythological. Western-trained scholars have pointed out, though not without argument, notably from Maung Htin Aung (1970), that while the Burmese chronicles exalt the dignity of the capital by having it founded so early, the earliest extant chronicle dates only to A.D. 1520, and contains only a few sentences on Bagan (Luce 1948:79-81; Than Tun 1988). Another conventionally ascribed founding date for Bagan, or at least its walled core, the mid-ninth century A.D. (see, for example, Ministry of Culture 1963 , e), appears to rely to a considerable degree on circumstantial evidence. According to traditional histories, King Pyinbya, whose origin was supposedly Pyinbya Village, to the east of the Pyu city of Beikthano, built Bagan's city walls, Sarabha gateway, and moat in A.D. 849 (Kan Hla 1977:15; Khin Maung Nyunt 1989). This is seen as being the consequence of an invasion, as recorded in Chinese annals, by the Buddhist kingdom/confederation of Nan-chao, which plundered an unidentified "capital" of the Pyu kingdom in A.D. 832, carrying off 3000 captives (Backus 1981:129; Luce 1961:91). This, says Luce (1959), allowed Bagan, settled by Burmans migrating westward from their agricultural holdings at Kyaukse, to fill the gap in the regional power structure. Luce $(1961: 117)$ nominates Halin (see Fig. 12) as the vanquished capital, though Mongmao, or Maingmaw, a 625 ha walled site rediscovered in the mid 1960s, would appear to have been just as big, just as close to the Chinese frontier, and just as accessible down the Ayeyarwady Valley from Nan-chao (Aung Myint 1999:23-46; Frasch 1996: 121; Sein Maung 1981). The Chinese incursion might not have even taken place in riverine Upper Burma. Aung-Thwin (forthcoming, Chapter 2) suggests that in the original text, the two places recorded as having been attacked by the Chinese, Mi No and Mi Ch'en, were coastal sites.

The "fall of the Pyu/rise of Bagan" hypothesis is therefore debatable. The notion that once attacked or plundered, a city has irrevocably fallen, would be disputed by the stakeholders of many cities of the ancient world, from Rome to Angkor. The quick and permanent redirection of Nan-chao aggression toward Annam, aided by Pyu allies or conscripts (Backus 1981:138), leaves unresolved the role of other large Pyu urban sites such as Binnaka, Sri Ksetra, Beikthano, and either Halin or Mongmao, if one of the latter two actually was the Pyu capital that "fell." And the available evidence from radiocarbon dating does not support 


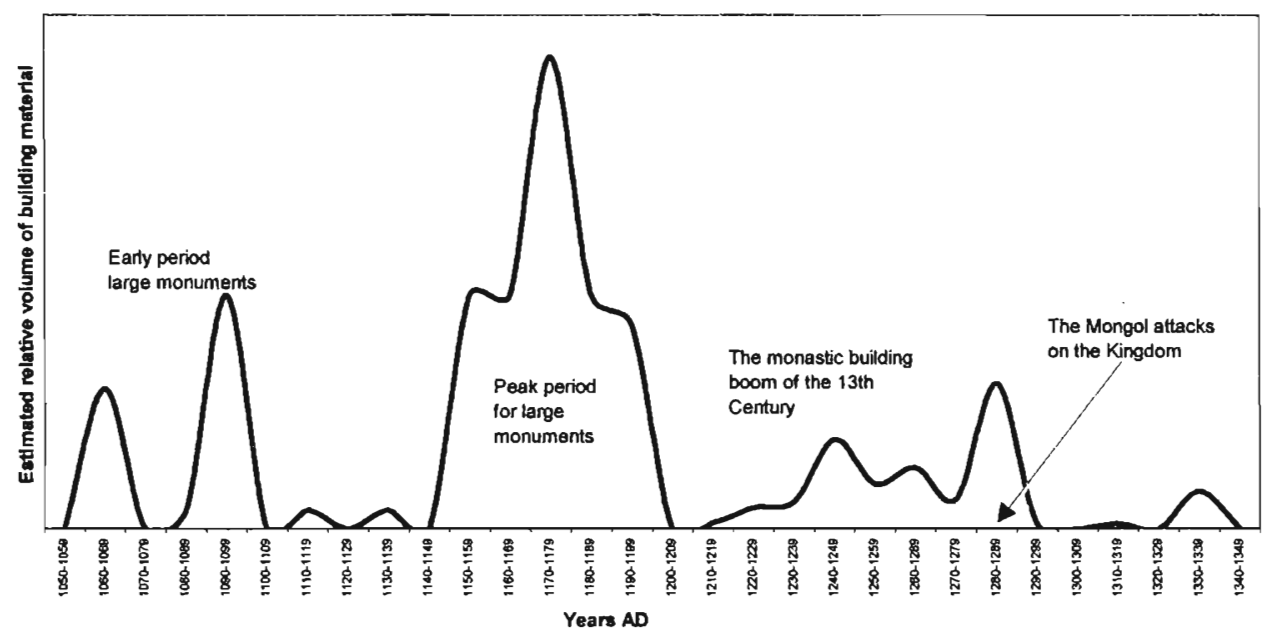

Fig. 1. The building cycle at Bagan A.D. 1050-1399. Time scale for 86 dated buildings at Bagan in relation to the estimated resources used.

the idea that Bagan's city walls were initially built in the ninth century as a response to the threat of Nan-chao. Current data puts the construction of the wall's eastern portions, at least, somewhere between A.D. 990 and 1230 (see Grave and Barbetti, this volume).

The epigraphic dates in the Inventory of Monuments, largely taken directly from inscription stones, are the core data for this study. ${ }^{3}$ We propose that these samples (Fig. 1) are sufficient to begin a statistical study of Bagan's date range, although it must be emphasized that further material awaits analysis and possible inclusion. The amount of dates available for each century is generally in proportion to the number of structures the Inventory of Monuments attributes to those centuries (Hudson 1997). The earliest date well attested by an engraved foundation stone is A.D. 1113 at the Kubyauk-gyi temple, near Myinkaba Village (Pichard 1995 : 250). Some early inscriptions exist only as copies, with consequent problems of authenticity. Many have been moved to museums or to other cities, notably by King Bodawpaya (1781-1819) who collected inscription stones to keep at his domain at Amarapura ( $A S B$ 1917:16). One of the earliest of these relating to Bagan appears to have had a date of A.D. 1058, recording a dedication of lands to an unidentifiable Letthe-she pagoda (Duroiselle 1921:5). However, the dubious provenance of many of these inscriptions, the lack of information about the location and dimensions of the buildings they refer to, and inaccuracies in copying the data ( $A S B$ 1917:16-17), have led us to err on the side of caution, and for now exclude dates not in the Inventory of Monuments.

\section{CONSTRUCTION SEQUENCE}

The building cycle at Bagan, according to Inventory of Monuments data, has several noticeable oscillations between the eleventh and thirteenth centuries (Fig. 1). These could reflect social, political, economic, or religious changes. The period during which the greatest volume of resources was used, as indicated on the 
graph, was the second half of the twelfth century A.D. This is also when most of Bagan's very large buildings, defined in the Inventory of Monuments as those which have an external dimension exceeding $50 \mathrm{~m}$ on their ground plans, were built (Pichard 1992). Trigger $(1990: 128)$ has proposed that as a general rule, the dedication of resources to substantial monuments during the early stages of an urban center is an indicator of a move to "consolidate new social, political and economic formations," and this would certainly appear to be the case at Bagan.

The timing of the early construction process does not, however, form a neat statistical curve. Building appears to have taken place in distinct phases. If the main A.D. 1150 to 1200 period of monument building is accurately reflected by the samples from the Inventory, it seems that it followed an earlier phase of construction between A.D. 1050 and 1100. King Anawratha (1044-1077) is credited in this period with imposing hegemony on much of the Ayeyarwady Valley, and he is represented by widespread deposits of votaries bearing his name (Luce 1969, vol. 1:15-27). Anawratha is said to have imported population and economic resources from Thaton, after invading that southern Mon city when it rejected his demand to be supplied with copies of Buddhist scriptures, although this entire issue has come under question from Aung-Thwin (pers. comm.), who suggests that the very existence of Thaton at this time is not supported either by epigraphy or by the early chronicles. Nonetheless, the rise to predominance of Theravada Buddhism, a religion that comes with a substantial assemblage of monuments, statues, and ritual items, is attributed to Anawratha's time, notably through his patronage of the monk Shin Arahan. The king is also said to have improved the irrigation system in Kyaukse, to the east, ensuring a good supply of rice to the capital by enforcing control over this valuable food resource (Aung Thaw 1972: 41; Ishizawa 1989; Khin Maung Nyunt 1997; Maung Hla 1923: 93).

The spatio-temporal evidence suggests that Anawratha, and the rest of the ruling elite of the second half of the eleventh century, was also engaged in a process of local consolidation. According to the data from the Inventory of Monuments, which periodizes Bagan's buildings by the century on the basis of such attributes as style and their association with epigraphically dated structures, construction in the eleventh century was spread for more than $9 \mathrm{~km}$ along the Ayeyarwady River upstream and downstream from what today is the walled area and presumed early elite center known as "Old Bagan" (Fig. 2a). This pattern of local rather than centralized construction suggests that several communities may have been involved in the move to monumentality, a move quite possibly initiated and encouraged by the emerging elite.

The physical consequence was that, as indicated by the patterning of monuments in the twelfth century (Fig. 2b), the time when maximum resources went into construction (Fig. 1), while buildings began to cluster around "Old Bagan" there was also continued growth up and down the river as well as into the eastern areas 3 or $4 \mathrm{~km}$ from the Ayeyarwady. By the thirteenth century, the area around "Old Bagan" had become so densely packed with monuments that major new clusters of buildings developed toward the east (Fig. 2c). These nodes, including the monastic area of Minnanthu, were not much further from the up and down river extremities of the city than they were from "Old Bagan." Physically, they could be accessed equally from any part of the city. In mechanical terms, the city still appears to have been catering to residents along the original $9-\mathrm{km}$ strip that 

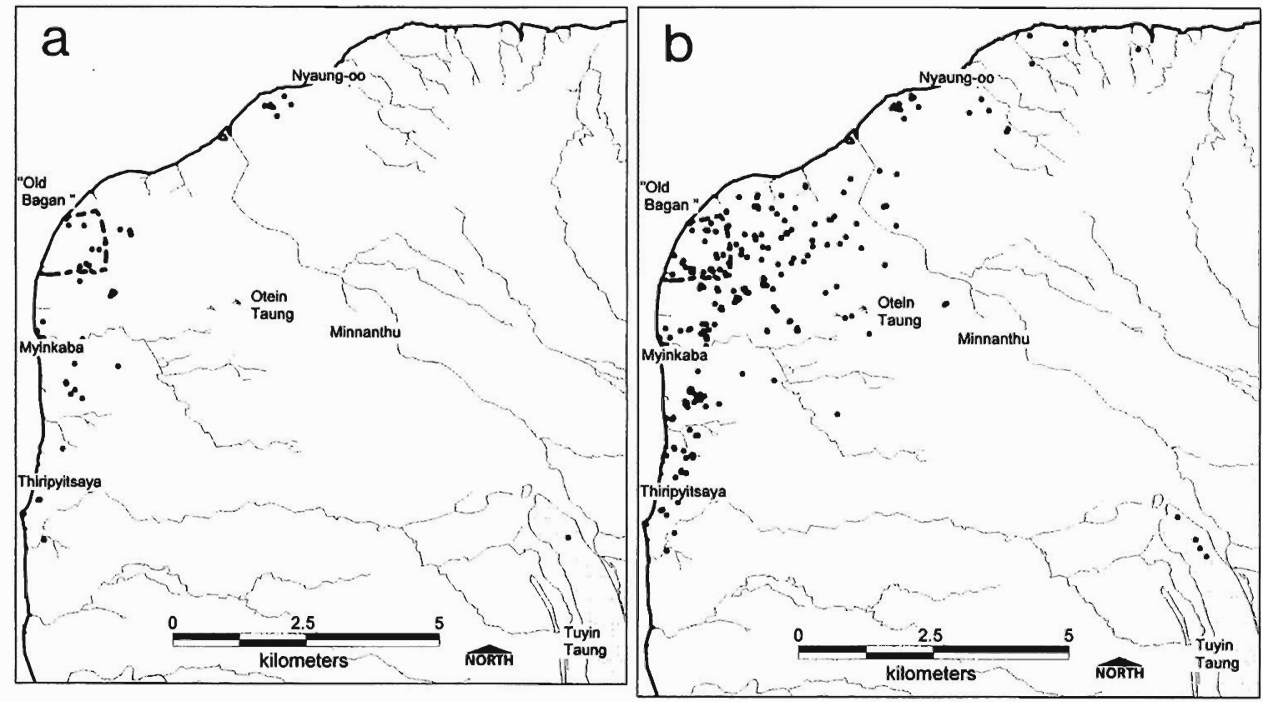

Fig. 2. Distribution of buildings, elevenththirteenth centuries A.D. a, eleventh century: Bagan defines its extremities; $b$, eleventhtwelfth centuries: monuments continue to accumulate; $c$, thirteenth century: monument density increases and several new nodes form.

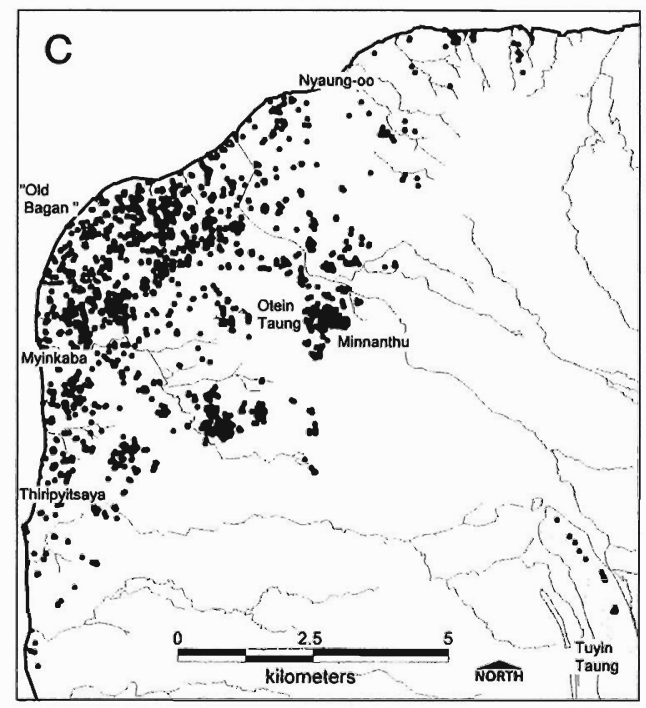

had defined its extremities two centuries earlier. We will suggest that the longterm presence of several local settlements is borne out by archaeological evidence.

During the thirteenth century, the Inventory of Monuments data also indicate that there was a significant upsurge in the building of monasteries and associated small structures. This cycle has been linked to dwindling economic resources, hence the smaller buildings, and to a broadening of monastic influence, hence the clustering of the buildings around monastic complexes and often within walled monastic compounds (see Aung-Thwin 1985). Changes in the religious, economic, or social constraints on donors of religious buildings in this period might also have been a significant element in the construction of these small buildings. We will suggest that a broadening of the parameters of donor activity may be detected in the evidence from archaeological excavations and survey. 


\section{POST-BAGAN}

By the middle of the fourteenth century A.D., the locus of power had moved upriver to the area around modern Mandalay. The conventional explanation for this, the alleged invasion and sacking of the city in the 1280 s by Kublai Khan's Mongol forces, is today considered to be poorly supported by historical evidence (Aung-Thwin 1998:63-92). Nor is it supported by the art history, despite the presentation by proponents of the "Mongol invasion" hypothesis of a picture of a Mongol archer on the walls of Bagan's Kyanzitta Umin as evidence of a Mongol military presence ( $A S B$ 1922:17-18; Universities Historical Research Centre 1996:6). Published versions of these pictures usually fail to show that the archer in the monastery wall painting is actually aiming at a duck, while a Mongol officer lounges nearby under a tree, with what appears to be a bird of prey perched on his wrist, in a scene far more bucolic than militaristic. This oft-cited but undated picture should really be viewed as no more than an appealing piece of graffiti.

A more likely explanation, as Aung-Thwin (1998) has suggested, is that the provincial administrators charged with defending Bagan's northern frontiers against Mongol incursions did so with such success that they became the new power elite, and their domains eventually became the locus of Burman administration. This left Bagan a backwater in terms of central control, although intermittent construction of buildings until colonial times indicates that while the city suffered from earthquakes, general deterioration, and vigorous pillaging (Than Tun 1996), it remained a monastic and pilgrimage center.

\section{EARLY BAGAN: BUILDING A CHRONOLOGY}

Bagan had not, until the 1990s, been the focus of any programs of absolute dating. In 1999-2000, Bob Hudson and Nyein Lwin excavated Otein Taung (Fig. 3) with the joint aims of investigating whether it might be an earthenware production site, commencing a program of pottery characterization and analysis and, due to the obliging nature of a site where fire was a significant factor, obtaining charcoal samples for radiocarbon dating. Otein Taung is essentially a descriptive term that means "pottery hill." The name has also been given to a mound of potsherds on the north side of the Pyu settlement of Beikthano (Aung Thaw 1968:71).

\section{THE OTEIN TAUNG MOUNDS}

The Otein Taung site, located $2 \mathrm{~km}$ southeast of the Ananda temple at Bagan (Figs. 3, 4), consists of two mounds $500 \mathrm{~m}$ apart, covered with dense layers of fragmented pottery, and with scatters of potsherds visible around and between them. The western mound is $90 \mathrm{~m}$ by $35 \mathrm{~m}$, and up to $7.5 \mathrm{~m}$ high. The eastern mound is $\mathrm{L}$ shaped. Each side is about $80 \mathrm{~m}$ long, at least $25 \mathrm{~m}$ wide, and more than $6 \mathrm{~m}$ high at the highest point. Cattle and goats regularly graze on the mounds. Plowed areas for crops such as maize come up to the edges, but local farmers say the mounds themselves are not plowed. The Otein Taung area contains clusters of mainly small monuments, which are attributed by the Inventory largely but not exclusively to the thirteenth century A.D. (Pichard 1994, monuments 809-840). 


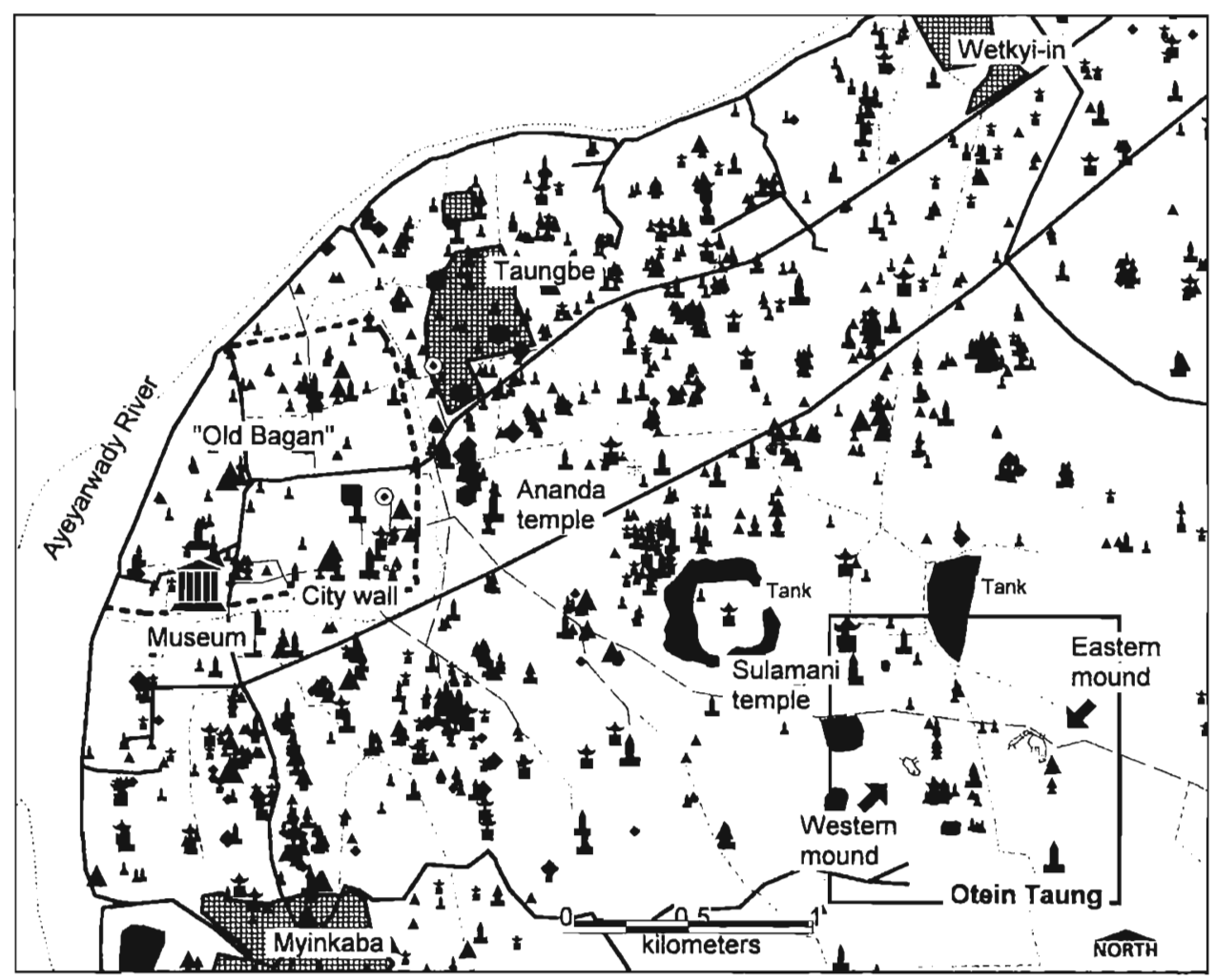

Fig. 3. Location of the Otein Taung mounds at Bagan.

\section{Trench, Test Pits, and Augering}

The first of two major test excavations undertaken at Otein Taung was a trench into the southern side of the eastern mound (Fig. 4, 1; Fig. 5). A test pit $1 \mathrm{~m}^{2}$ was dug $100 \mathrm{~m}$ southeast of this (Fig. 4, 2) plus a 7-m-deep test pit that went from top to bottom of the western mound (Fig. 4, 3; Fig. 6). Each of these yielded samples that have been radiocarbon dated. A fourth test pit $100 \mathrm{~m}$ northwest of the trench revealed, as did the pits that provided datable material, a lens of fine gray potash about $1.5 \mathrm{~m}$ below the surface. Augering on and around the eastern mound suggested a consistent stratigraphy, with a meter and a half of mixed clay, wood carbon, sand, potsherds, and soil typically lying above ash lenses. The ash lenses contained potsherds, small pieces of charcoal, visible filaments of burned bamboo, and in the case of the trench excavation, animal bones and pigs' teeth. The generally fine consistency of these layers of potash suggests that bamboo and other grasses provided the bulk of the fuel.

\section{Function of the Site}

It is not certain at present whether Otein Taung is an earthenware production site, or a huge, and for Bagan unique, residential midden. While it is not essential to make this distinction to validate the radiocarbon-based chronology, it may be 


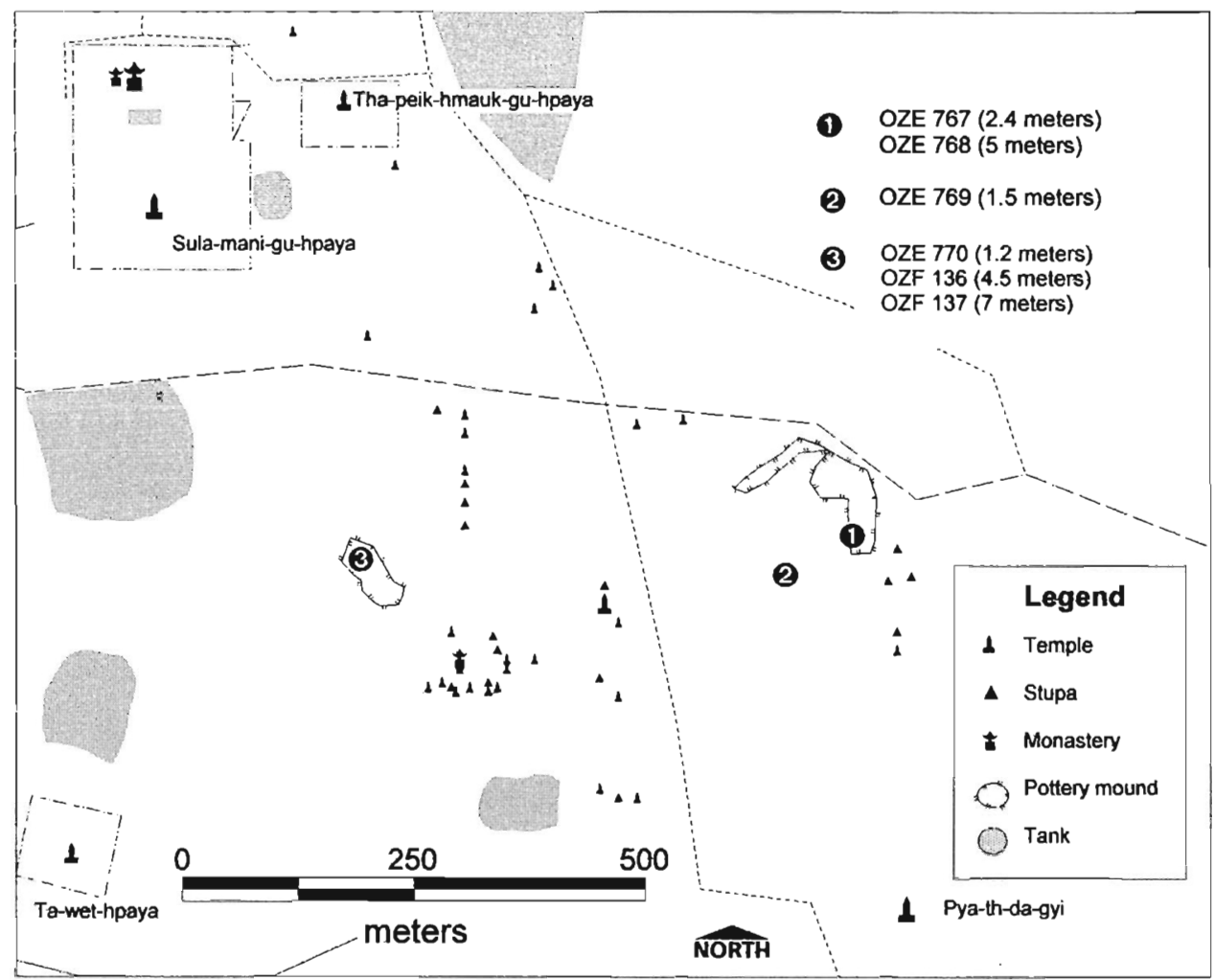

Fig. 4. Location of charcoal sampling for radiocarbon dating at Otein Taung.

useful to summarize the data acquired so far, although full reporting and analysis of the finds will be the subject of a future paper.

One key problem is to distinguish production debris from domestic debris, particularly when potters might be assumed to have been users of their own products. Imported items could, by the same token, represent either household goods or "professional" supplies, used by potters for copying or inspiration. Ethnographic observations by the authors of specialist pottery-producing villages at Twante, west of Yangon (Rangoon), Sagaing (near Mandalay), Chiang Mai (Thailand), and Ban Jaan, near Luang Prabang, in Laos, suggest that production and residential sites in the region today are not differentiated. However, this may be a characteristic of modern villages, where family units produce pottery on their own properties, and cannot be projected on to earlier times.

No slumps characteristic of overfiring in a stoneware kiln were found at Otein Taung, nor any large brick or earth structures suggesting a pottery kiln. While several small kilns containing glassy residues have been located at Bagan, all within a kilometer or so of the river, their function remains a disputed topic (Aung Kyaing 1999; Dello Strogolo and Kyaw Nyein 1963; Hein 1996; Rooney 1999). The Otein Taung site yielded only occasional surface fragments of glazed ware, some obviously modern. This does not rule out a site dedicated to openfield earthenware production. Clay resources are available. The subsoil at Bagan 


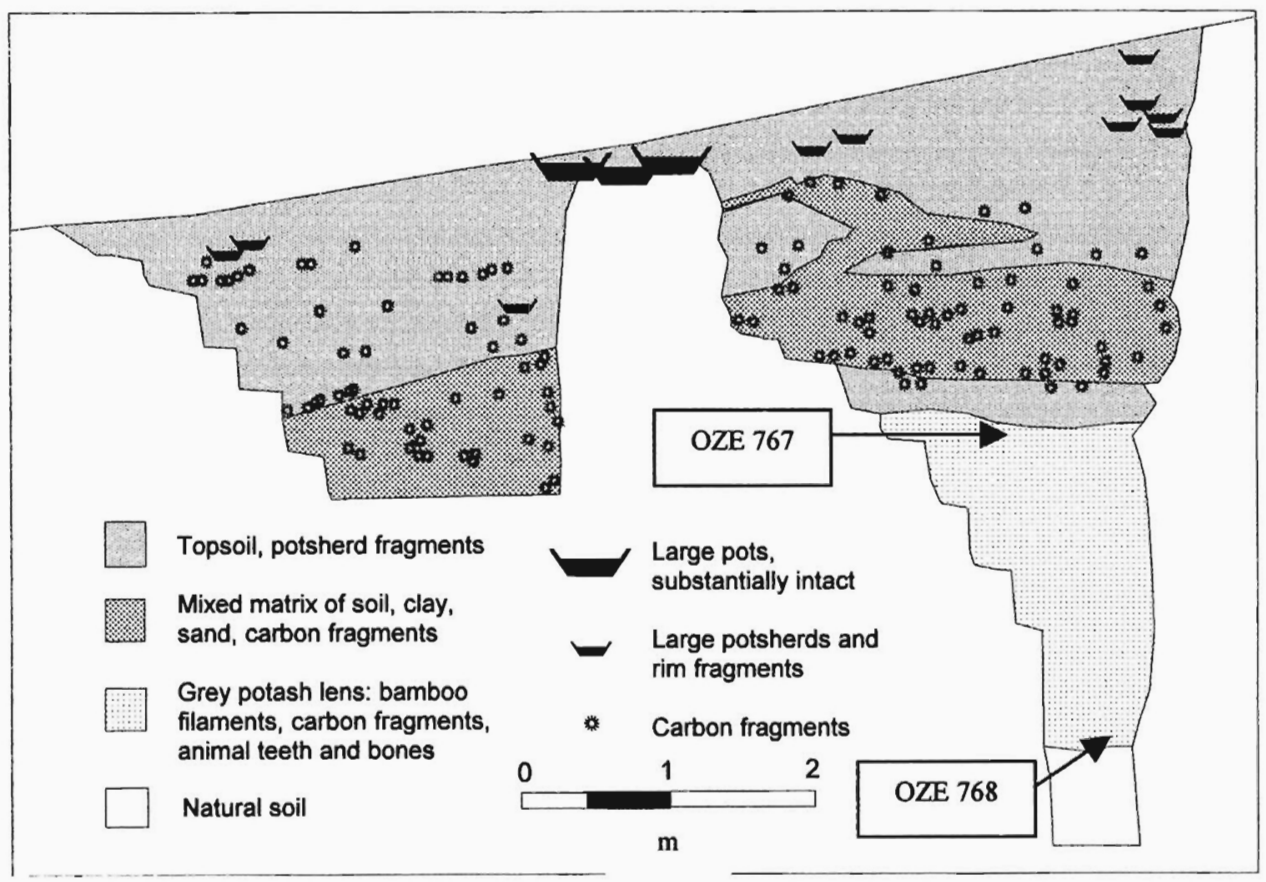

Fig. 5. Stratigraphy and sampling details, Otein Taung eastern mound.

contains clay that is still mined today for brickmaking. There are four tanks within $500 \mathrm{~m}$ of the Otein Taung site (Fig. 4) that may have originally been clay pits. One of these, south of the Sula-mani pagoda, was a brickmaking site in recent times, as evidenced by scatters of burned brick, and quarrying has left large patches of clay exposed.

\section{Earthenware Assemblage}

The tentative "production site" hypothesis is supported at Otein Taung by several earthenware anvils that were either excavated or found during surface collection. These are common potters' tools in South and Southeast Asia, held inside the green pot while it is beaten on its outer surface with a paddle. The paddle-andanvil process has been portrayed in eighteenth-century temple drawings at Bagan (Fraser-Lu 1994:207), and recorded ethnographically in colonial and modern Burma (Reith 1997; Taw Sein Ko 1895).

Sherds excavated at the eastern Otein Taung mound all appeared to have been produced with anvil and beater. However, the excavation also uncovered a $10-\mathrm{cm}$ solid clay tube, $1.8 \mathrm{~cm}$ in diameter, with a circular "spokes of a wheel" pattern on one end, which may have been a stamp for decorating pots. This technology was well established in the region by the first millennium A.D. and can be observed at Beikthano (Aung Thaw 1968:138-139). Pottery with various stamped designs was also found in a test pit on the western mound. Our local workers, all domestic users of earthenware, were readily able to nominate sherds and rims we excavated as belonging to water pots, cooking pots, or plates as they sorted the mate- 


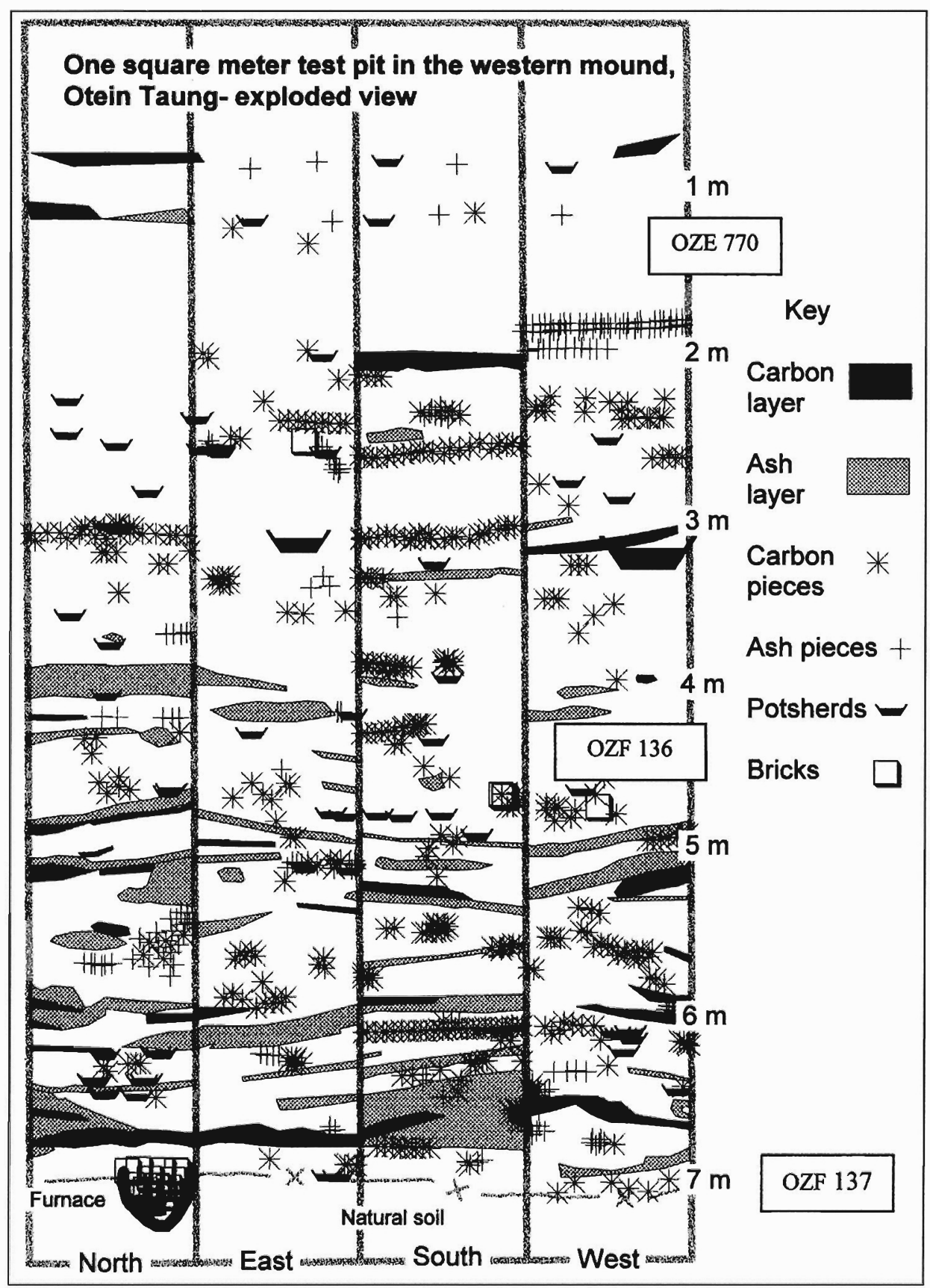

Fig. 6. Stratigraphy and sampling details, Otein Taung western mound.

rial to be photographically recorded and stored for a future program of detailed characterization. None identified the anvils or the putative stamp as such, perhaps due to unfamiliarity with pottery production. Glazeware and most earthenware is today brought from upriver, sometimes floated down on rafts that are themselves 


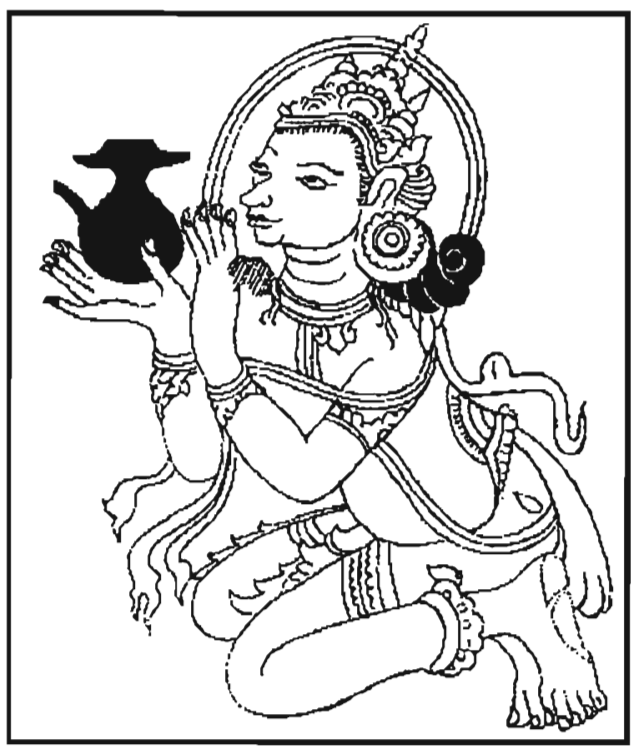

Fig. 7. Offering water in a sprinkler pot, from a Bagan-period wall painting (after Myint Aung 1969).

made from large pots lashed together, although there are still at least two villages in the eastern hinterland of Bagan, Ngathayauk and Taunggon, making earthenware for local consumption.

\section{Sprinkler Pots}

Perhaps the earthenware item most characteristic of medieval Buddhist sites in Myanmar is the sprinkler pot, or kendi (Fig. 7). These are found across South and Southeast Asia, generally attributed to the first and early second millennia A.D., from Pakistan (Di Crocco 1990) to Laos (Hein et al. 1992) and down the Malay peninsula (Khoo Joo Ee 1991) to Java (Adhyatman 1987), though it is only in the Buddhist countries that their function appears to focus on ritual libation (Myint Aung 1969). Buddhist cosmology and practice are bound up with the ritual pouring of water, reflecting the story of how Buddha, at the moment of his enlightenment, was able to call on the water he had poured in previous lives to witness his good deeds to come back and wash away the forces of evil. More than 50 spouts from libation pots were recovered from surface collections at Otein Taung and smaller numbers of spouts and necks were excavated to a depth of $2 \mathrm{~m}$. The spout samples were all straight, in contrast to the bent, squat spouts found at the Pyu city of Beikthano (Aung Thaw 1968:134).

The finds in the trench at Otein Taung also included part of a pot caked on its inner surface with bright red dried clay, which suggests that it may have originally contained slip. Sprinkler pots coated in slip are on display in the Bagan museum, and almost all the spouts found at Otein Taung had been slipped. Inscriptions at Bagan curse those who attempt to thwart the deeds of the person who has made a libation offering with being smashed "as the pot is smashed" (Aung Kyaing, pers. comm.). If libation pots were meant for single, ritual use, it is reasonable to expect a high volume of production, but one would also expect many broken pots 
at any site where ritual activities may have taken place, and such activity at Otein Taung cannot be discounted.

\section{Tiles and Tubes}

Roof tiles were found at Otein Taung, turned to a right angle at the short end and with an incised longitudinal central slot on the upper surface. Similar roof tiles were excavated by the Bagan Archaeology Department within the walled core of Bagan in the early 1990s, from a large and still open site generally described as a palace, and are kept with the Otein Taung material at the archaeology department's store. Fragments of open-ended earthenware tubes were also excavated. They are similar to samples excavated in "Old Bagan," which are thought by the archaeology department to have lined latrines. Up to eight of these tubes, substantially complete and measuring around $60 \mathrm{~cm}$ long and $40 \mathrm{~cm}$ in diameter, were found vertically above each other at "Old Bagan" (Aung Kyaing, pers. comm.). Similar tubes were excavated in 1907 at a monastery in Si Satchanalai, Thailand (Siam Society 1986, end paper).

\section{Radiocarbon Dates}

The radiocarbon dates for Otein Taung suggest that the site functioned over many centuries. ${ }^{4}$ In the eastern mound, at the top of the gray ash lens in the trench (Fig. 4, 1; Fig. 5), $2.4 \mathrm{~m}$ down, sample OZE 767 dates A.D. 1290-1410. Directly below this, at $5 \mathrm{~m}$, in the lower part of the uninterrupted ash lens, were pigs' teeth, bones, potsherds, and sample OZE 768, which has a date range of A.D. 880-1030. The top and bottom samples from the ash lens in the trench were chosen for radiocarbon dating because they appeared to represent a continuing event, and the results do indeed suggest a secure stratigraphy in this part of the site. The presence in the lens of pigs' teeth and ruminant bones, well preserved in the alkaline matrix, might suggest that the users of the site cooked meals on the hot ashes, and later threw the bones only as far as they needed to.

Southwest of the trench, $100 \mathrm{~m}$ across an agricultural field, a test pit (Fig. 4, 2) was dug down to an ash lens which appeared at $1.5 \mathrm{~m}$. This lens contained potsherds as well as carbon fragments. Sample OZE 769 gives a date range of A.D. 760-980.

A $1-\mathrm{m}^{2}$ test pit was also dug in the western mound, to a depth of over $7 \mathrm{~m}$ (Fig. 8). Radiocarbon samples OZF 136 and OZF indicate activity in the lower part of this pit between A.D. 1010 and 1220. A date range of A.D. 650-830 from sample OZE 770 near the top of the pit could suggest the redeposition of earlier burnt material, or perhaps the use of very old wood, but it is essentially an aberration, and for the sake of chronometric hygiene will not be considered to be directly relevant to the age of the site. It should be noted that sample OZF 137 came from inside a small furnace or stove that appears to have functioned below the levels of ash and pottery. Fragments of yellowish white glass were collected around this object, which had an upper half filled with bricks. A perforated earthenware grid sat across the furnace, presumably to allow air to flow up from a lower chamber. The glass did not appear to have been worked as one might expect if beadmaking had been involved, and for now the furnace must simply be 
Table I. Radiocarbon Dates of Otern Taung Charcoal Samples: Australian Nuclear Science and Technology Organization (ANSTO)

\begin{tabular}{|c|c|c|c|c|c|c|}
\hline $\begin{array}{l}\text { SAMPLE: CODE, LOCATION, } \\
\text { STRATIGRAPHY }\end{array}$ & $\begin{array}{l}\text { PERCENT } \\
\text { MODERN } \\
\text { CARBON }\end{array}$ & $\begin{array}{l}\text { ONE } \Sigma \\
\text { ERROR }\end{array}$ & $\begin{array}{c}\text { DetTa }\left({ }^{13} \mathrm{C}\right) \\
\text { ASSUMED } \\
\text { VALUe } 25.0\end{array}$ & $\begin{array}{l}\text { DeLta }\left({ }^{13} \mathrm{C}\right) \\
\text { MEASURED } \\
\text { VALUE }\end{array}$ & $\begin{array}{l}\text { RADIOCARBON AGE, } \\
\text { ROUNDED }\end{array}$ & $\begin{array}{l}\text { CALIBRATED } \\
\text { DATE RANGE A.D. } \\
\text { (OXCAL V3.5) }\end{array}$ \\
\hline $\begin{array}{l}\text { OZE } 767 \text { Eastern mound, } \\
\text { top of ash lens }\end{array}$ & 92.5 & 0.41 & $626 \pm 36$ в.P. & $624 \pm 36$ B.P. & $620 \pm 40$ в.P. & $\begin{array}{l}1290-1410 \\
(95.4 \% \text { probability) }\end{array}$ \\
\hline $\begin{array}{l}\text { OZE } 768 \text { Eastern mound, } \\
\text { bottom of ash lens }\end{array}$ & 87.34 & 0.39 & $1088 \pm 36$ в.P. & $1086 \pm 36$ в.P. & $1090 \pm 40$ в.P. & $\begin{array}{l}880-1030 \\
\quad(95.4 \% \text { probability) }\end{array}$ \\
\hline OZE $769 \mathrm{Pit}$ in field at $1.5 \mathrm{~m}$ & 86.22 & 0.36 & $1191 \pm 34$ в.р. & $1192 \pm 34$ B.P. & $1190 \pm 40$ в.P. & $\begin{array}{l}760-980 \\
\quad(89.9 \% \text { probability) }\end{array}$ \\
\hline $\begin{array}{l}\text { OZE } 770 \text { Western mound, at } \\
1.2 \mathrm{~m}\end{array}$ & 85.11 & 0.33 & $1295 \pm 31$ в.P. & Not obtainable & $1290 \pm 40$ в.P. & $\begin{array}{l}650-830 \\
\quad(93.6 \% \text { probability) }\end{array}$ \\
\hline $\begin{array}{l}\text { OZF } 136 \text { Western mound, at } \\
4.5 \mathrm{~m}\end{array}$ & 89.32 & 0.40 & $907 \pm 36$ в.P. & Not measured & $910 \pm 40$ B.P. & $\begin{array}{l}1020-1220 \\
\quad(95.4 \% \text { probability) }\end{array}$ \\
\hline $\begin{array}{l}\text { OZF } 137 \text { Western mound, at } \\
7 \mathrm{~m} \text {, in bowl furnace }\end{array}$ & 89.00 & 0.42 & $936 \pm 38$ в.P. & Not measured & $940 \pm 40$ в.P. & $\begin{array}{l}1010-1190 \\
\quad(95.4 \% \text { probability) }\end{array}$ \\
\hline
\end{tabular}




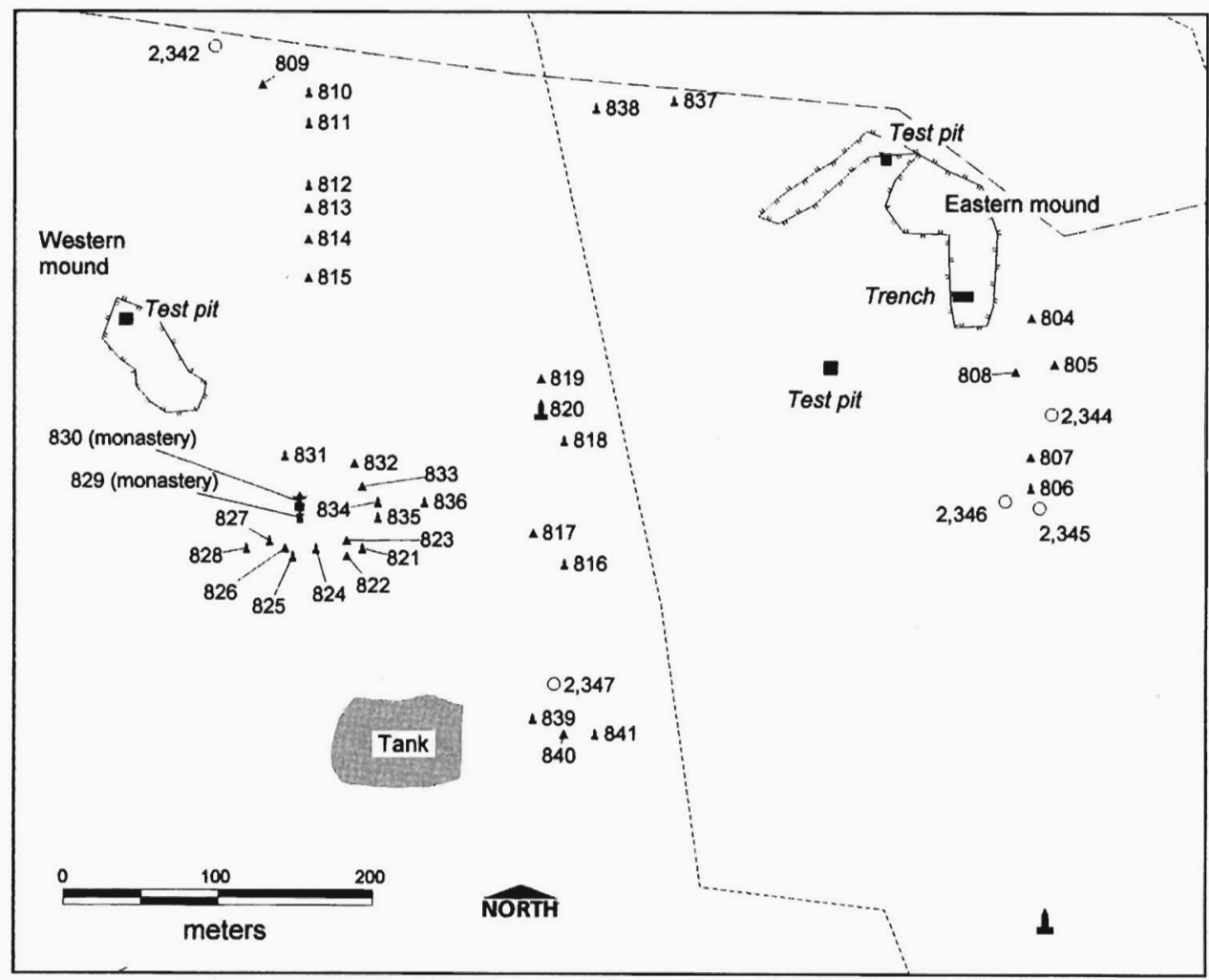

Fig. 8. Detail of the Otein Taung monument cluster. 820: large temple with unique stucco windows, attributed to the twelfth century A.D., restored in 1999; 832: small stupa, possibly dates to the twelfth century; other buildings attributed to the thirteenth century.

considered as some kind of equipment involving heat technology. It awaits further investigation.

\section{A Tentative History}

We now propose a tentative history of Otein Taung, based on a combination of archaeological evidence, notably the radiocarbon dates, and data from the Inventory of Monuments. It appears that by the ninth century A.D. (sample OZE 769) people in this area had begun to create an accumulation of debris involving pottery and burnt carbon-based materials. In the twelfth century, the settlement appears to have supported the construction of a large temple, monument 820 , halfway between the two mounds, by ceding land and by providing resources in the form of bricks. By the thirteenth century, the very proliferation of small monuments across Bagan suggests that the religious merit that accrued from endowing an individual monument was more widely accessible. Around 40 mainly small (less than $12 \mathrm{~m}$ maximum external ground dimension) monuments were built at Otein Taung (Fig. 8). Some of these buildings cluster around a monastery, on the south side of the western mound. A line of monuments running directly north to south $(810$ to 815$)$ might suggest a property boundary or a road. There is a fur- 
ther cluster south of the eastern mound, and monuments scattered randomly in the area between the two mounds.

\section{SETTLEMENT PATTERN}

If the proliferation of small monuments in the thirteenth century does in fact represent an increase in participation in monument building at the village level, then investigation in some of the other clusters could pinpoint other habitation sites (Fig. 9). This is not to say that other factors, such as the attraction of existing sacred buildings, might also contribute to the grouping of monuments. We have already suggested that the spread of monuments north and south of "Old Bagan" in the eleventh century may reflect the existence of several villages at this time. The legendary history of Bagan has it founded from a confederation of nineteen villages in the second century A.D. (Pe Maung Tin and Luce 1923). A number of sites traditionally nominated as original founding villages have been surveyed or excavated by the authors (Hudson et al. 2001) but they are spread quite widely, with only five of them within $5 \mathrm{~km}$ of "Old Bagan." Whatever evidence may eventually appear about the intraregional origins of Bagan, we need a more useful model of local functionality. McIntosh $(1991,1999)$ provides one such model. He suggests a spatial pattern he calls "urban clustering," in which a network of communities, occupied contemporaneously and in close proximity, provide services to a large hinterland. McIntosh gives as an example Jenne-jeno, a first millennium A.D., 69-ha urban cluster in Nigeria containing one major settlement, and 21 smaller satellites, many with evidence of specialist occupation. He points out that this form of clustered urban complex had also appeared in Shang China, at Cheng-chou and An-yang, where the settlements in their early phases formed networks of discrete nodules. The essential feature of these communities is that they gravitated together while avoiding assimilation into a single entity. In the social experiment that was urbanism, people would have needed to deal with what Fletcher (1995) calls the stresses of interaction and communication. One way of doing this at Bagan may have been for various groups who were defined or defined themselves by ethnicity or occupation to live in clusters of villages. Mon, "Mranma" (Burman), and Pyu are regularly distinguished from each other at Bagan in early documents or inscriptions, sometimes in terms of specialist occupations such as soldier, farmer, toddy-climber, musician, dancer, elephantkeeper, mason, or potter (Aung-Thwin 1994:27; Luce 1940, 1959:86-89). Bagan's four-language Myazedi inscription of the early twelfth century (Taw Sein Ko and Duroiselle 1919) also distinguishes the Pyu linguistically from the Mon and the Burmese, with Pali linking the Buddhist-educated members of those groups.

\section{THE PYU LANDSCAPE}

One form of self-definition common in the region at the time does not appear to have functioned at Bagan: the community did not live inside a wall. An allencompassing brick wall is a key feature of a number of first millennium A.D. urban centers in the upper Ayeyarwady basin. With walls characteristically circular or oval, these settlements share geographical, physical, and cultural features, 


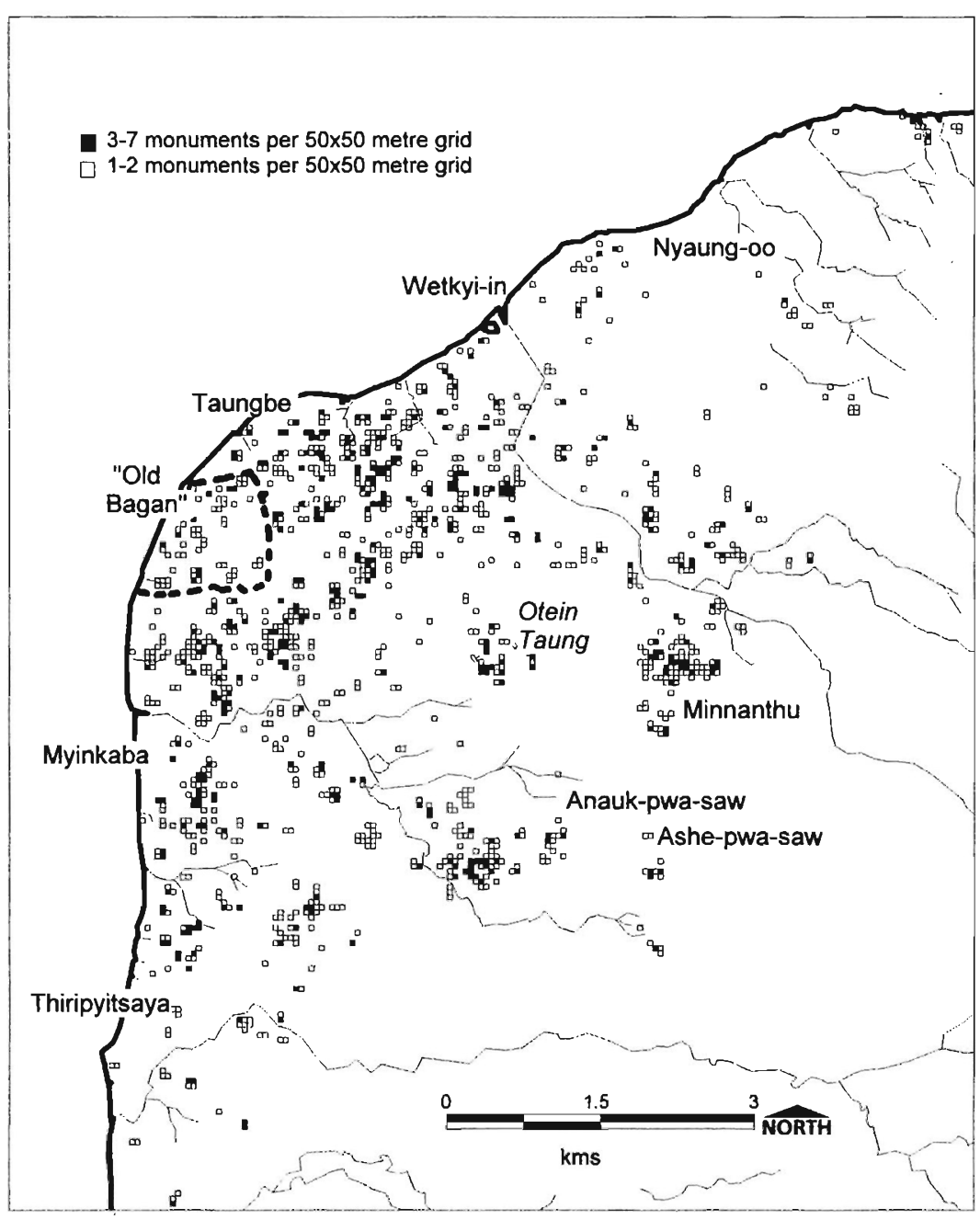

Fig. 9. Monument clusters at Bagan, eleventh to thirteenth centuries A.D., provide a possible key to early settlement locations.

which lead to their being identified as "Pyu." Six of them-Halin, Waddi, Mongmao, Beikthano, and neighbors Sri Ksetra and Thegon (Fig. 10), ranging in size from 200 to 1400 ha-were surveyed by environmental scientists Donovan, Fukui, and Itoh (1998) who found that along with the common feature of enclosure by brick walls, their location on high ground and a consistent regional ecology suggested that "the economy, if not cultural life, of the Pyu societies was 'closed' while that of Bagan was 'open' in the sense that the latter commanded different ecological zones from a single center." There are similar enclosed settlements in Arakan (Rakhine) on the west coast of Myanmar, separated from this group by a substantial mountain range, and smaller ones to the south, near the mouth of the Ayeyarwady.

The enclosed settlement appears in other parts of Southeast Asia in the first 


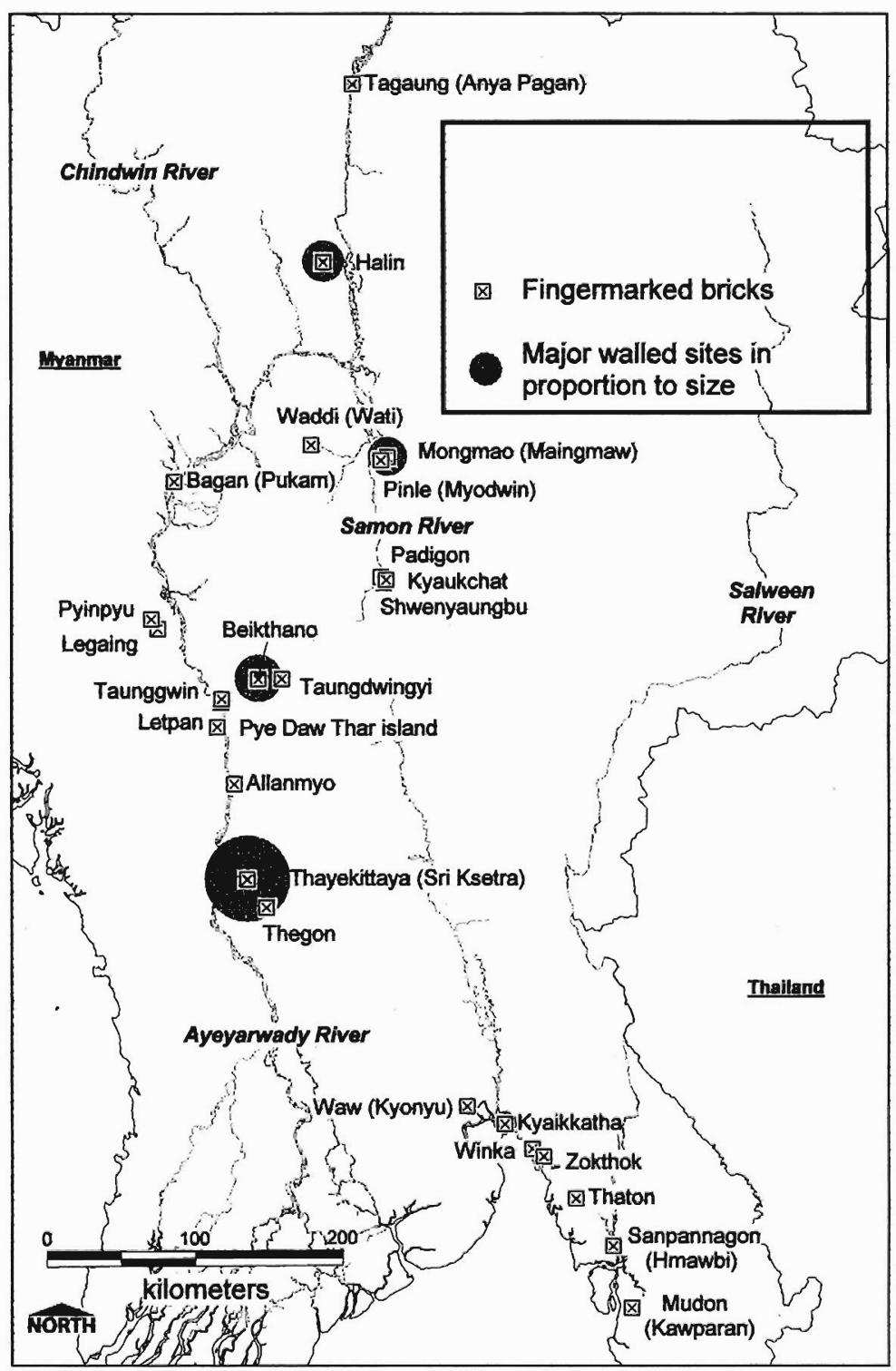

Fig. 10. Settlements with "Pyu" characteristics in Myanmar, first millennium A.D., indicating the distribution of Pyu bricks found in early urban settlements.

millennium A.D. A network of moated settlements appears to have formed a regional economic system in the central plain of Thailand by the ninth century A.D. (Mudar 1999). Similar sites, seen as having both water-harvesting and territorial functions, existed in the Mun River basin of northeast Thailand (Higham 1989:217-228; Moore 1988). In the case of the Myanmar settlements, at least, this residence within a communal enclosure does not necessarily suggest social homogeneity. Beikthano (Aung Thaw 1968:71), Halin (Myint Aung 1970), Mongmao (Sein Maung 1981), and Thayekittaya, also known as Sri Ksetra, Hmawza, 
or Old Prome (ASI 1910, pl. 11), all had what appear to be elite enclosures within their outer walls.

\section{PERIODIZING THE PYU SETTLEMENTS}

Myint Aung (1970:55) suggests that the time sequence for the major Pyu centers is Beikthano earliest, then Halin, then Thayekittaya. The scientific evidence indicates a considerable overlap for Beikthano and Halin. Radiocarbon dates at Beikthano of $1950 \pm 90$ B.P. (sample I 434, Radiocarbon 1963) and $1890 \pm 95$ B.P., $1725 \pm 95$ B.P. and $1650 \pm 85$ B.P. (Stargardt 1990:408) indicate activity there, according to current calibration of the data, between 180 B.C. and A.D. 610 . Mongmao, which on the basis of size deserves to be ranked with these three, has been dated comparatively to between the second and sixth centuries A.D. (Sein Maung 1981). The published radiocarbon dates for Halin (HL 9: $1370 \pm 59$ B.P.; HL 10: $1810 \pm 60$ B.P.; and HL 17: $1740 \pm 60$ B.P. [Myint Aung 1970:62]) indicate activity there between A.D. 70 and 780 .

Thayekittaya is said by the chronicles to have been founded in 443 B.C. (Pe Maung Tin and Luce 1923:6-28), though this has not been confirmed by any absolute method such as radiocarbon dating. The city has been extensively excavated since the early twentieth century (see ASI 1909-1912, for example) and while its foundation remains an open question, architecture, art history, and inscriptions place the major activity at Thayekittaya in the second half of the first millennium A.D. Aung Thaw (1972:16) suggests that the city "attained the height of its prosperity" between the fifth and ninth centuries, while the official brochure handed to visitors at the "Sriksetra Ancient City" museum proposes the fourth to tenth centuries A.D. Inscriptions on stone burial urns mark the deaths of members of the city's ruling elite in A.D. 688, 695, and 718 (Blagden 1917:43; Luce 1969, vol. $1: 5)$. Thayekittaya was still important enough to be referred to as the "capital" by the founders of Bagan in the eleventh century (Luce 1969, vol. 1:55) and was still prosperous enough to be worth ransacking, according to some reports, in the eleventh and even the sixteenth centuries (ASI 1910:115-116). Spatial evidence also hints that Thayekittaya was the most recent of the "Pyu" cities. A considerable number of its buildings are outside its walls, something unique among the walled Pyu settlements. If the fortification of the Pyu cities related to intercommunal stress, then it could be suggested that the extramural expansion at Thayekittaya was possible because the other cities were no longer its rivals within the context of Pyu settlement behavior. This does not discount the expansion taking place when Thayekittaya was under the hegemony of Bagan, in a new political and military environment.

\section{PYU SITE TYPES}

Enclosed sites appear to have been the main form of "Pyu" Iron Age settlement in Upper Burma, but it should be stressed that this was not the only type. While more than 40 walled sites have been located in Myanmar (Aung Myint 1999, pers. comm.; Luce 1969; Win Maung 2000), at least one area, around Binnaka $\left(96.1837^{\circ} \mathrm{E}, 20.6161^{\circ} \mathrm{N}\right.$ ), a cluster that includes Padigon and Kyaukchat (Fig. 10), has a substantial assemblage of material identified locally as "Pyu" including carnelian beads, pot-cremation burials, and fingermarked bricks, but with no evi- 
dence of past enclosure (Win Maung n.d.). Iron tools and weapons are found at the major enclosed Pyu settlements (for example, Aung Thaw 1968:53), while the Thayekittaya Museum has a permanent display of iron architectural fasteners, some more than half a meter long.

Field observation indicates that early, though so far undated, ironworking took place at $\mathrm{Zi}-\mathrm{o}\left(95.0411^{\circ} \mathrm{E}, 21.1087^{\circ} \mathrm{N}\right)$ in the eastern hinterland of Bagan. There are also 14 apparently unenclosed villages named Thanbo, "ironmaking village," in the region bounded by Halin, Mongmao, Beikthano, and Bagan, and only two others in the remainder of the country (CALLE 2001, NIMA 2001). This linguistic hint, while as yet uncorroborated by field survey or excavation, could point to further Pyu era sites. Identifying the open sites, and periodizing and characterizing them along with the enclosed early urban settlements in Myanmar, the majority of which are at present undated, is a project still in its early stages and currently the subject of database compilation (Hudson 2001). One useful proposal from Aung Myint (pers. comm.) in relation to the enclosed sites is that since a number of cities known to post-date Bagan, such as Toungoo, have a "formal" square or rectangular structure of single wall and wide moat, then settlements with this structure should be excluded from consideration as first millennium A.D. sites unless there is other evidence of early occupation.

\section{PYU BAGAN}

Bagan does not fit the physical or landscape model proposed as typically Pyu. It is not enclosed by a large irregular brick wall or a series of walls. Its location directly on the bank of the Ayeyarwady, as distinct from a characteristic Pyu location away from any main river and at the confluence of minor streams (as described in Stargardt 1990), and the more-or-less rectangular structure of the existing wall suggest a different kind of settlement behavior. The three-sided walled center also takes up only 140 of the city's 8000 ha devoted to monuments. This strongly suggests, in the light of the much greater enclosed areas of the major Pyu settlements (up to 1400 ha for Thayekittaya), that "Old Bagan" represents an elite core, not an urban boundary. A western wall may have been washed away by the river during or after the major occupation period at Bagan (Thin Kyi 1964). An undated traditional folding book (Parabaik 495 n.d., in the possession of Maung Maung Tin of the Myanmar Historical Commission) describes Bagan as having four walls and twelve gates. Observation in the field confirms that the Ayeyarwady has eroded parts of the city. There are buildings collapsing into the river both upstream and downstream from the walled core, and a walk along the riverbank from Nyaung-oo in the north to the Lokananda pagoda in the south reveals dense scatters of brick. However, whether there were originally three or four sides, the size and shape of "Old Bagan" distinguish it from the Pyu settlements.

There is nonetheless substantial evidence of a "Pyu" cultural assemblage at Bagan. The widespread presence there of distinctive Pyu fingermarked bricks has become evident during the past few years as hundreds of buildings were renovated or rebuilt. ${ }^{5}$ Many of these were to various degrees disassembled. Some were reconstructed completely from their rubble foundations in an officially sponsored restoration drive (Hudson 2000). Bricks found at Pyu sites across Myanmar are often deeply indented with several strokes, usually described as fingermarks (see Fig. 11, and for further examples, Aung Myint 1999; Aung Myint and Moore 

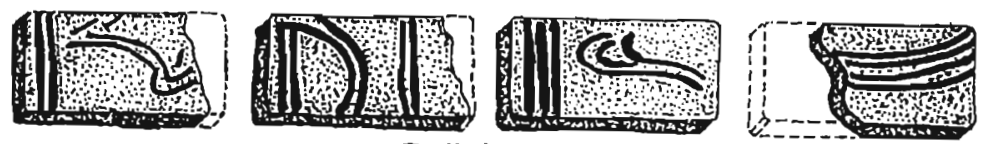

Beikthano
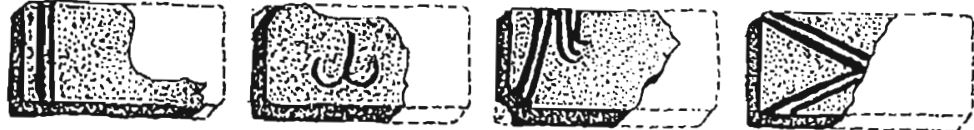

Halin
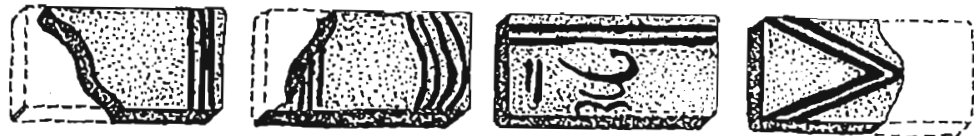

Sri Kshetra
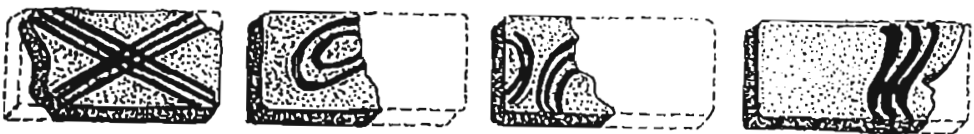

Pinle (near Mongmao)
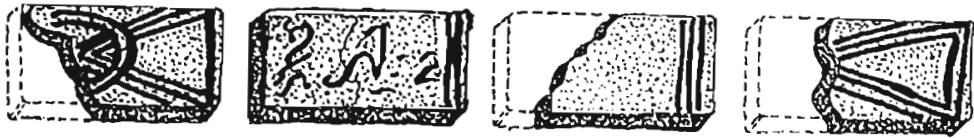

Taungdwin-gyi
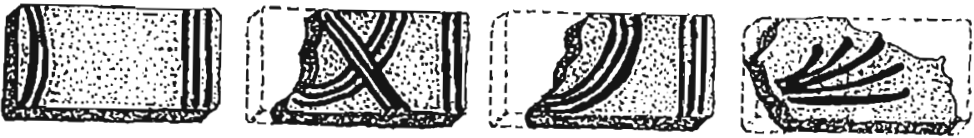

Padigon
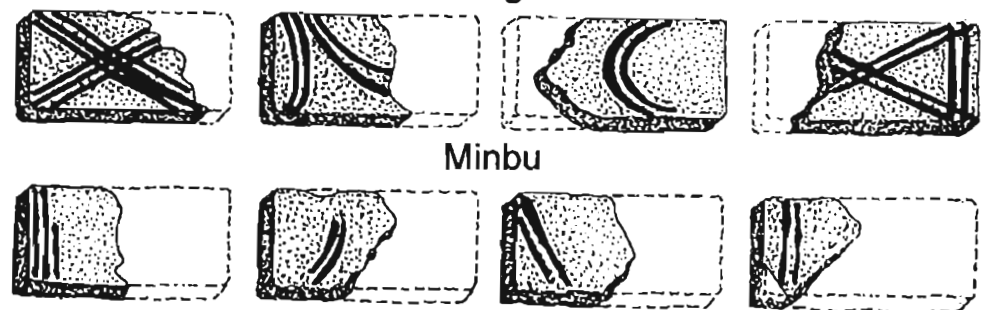

Minbu

Tagaung

Fig. 11. Examples of Pyu brick design at early settlements in Myanmar/Burma.

1991). Aung Myint (Moore and Aung Myint 1993:63) some years ago briefly noted the presence of Pyu bricks at Bagan, as distinct from bricks scored or stamped in Old Burmese script with the names of donors or donor villages. Field survey by Win Maung of buildings under renovation has now revealed at least 55 structures with bricks that appear to carry Pyu fingermarked designs (Fig. 12). These bricks are found in buildings across the time span of medieval Bagan (Fig. 13), including the large temple, 820 , in the center of the Otein Taung site (Fig. 8). Pyu-style earthenware vessels were found early last century at an area then known as Myinpagan, outside Bagan's walled core, during the digging of a well at a depth of $8 \mathrm{~m}$ (ASB 1917:42). Of "elongated shape and antique pattern," they were identified as Pyu by government archaeologists who, while not of a mindset 

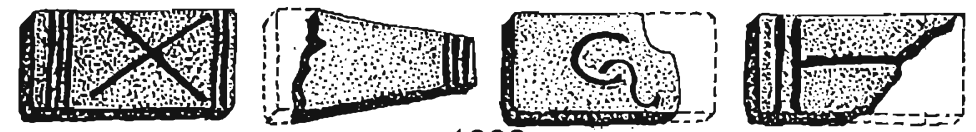

1339
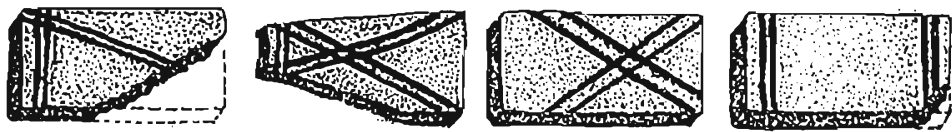

1662
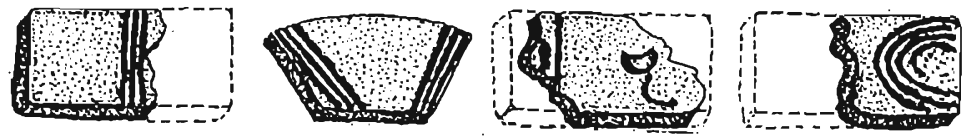

1704-1667
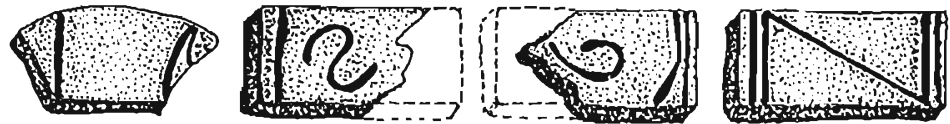

Mound near Payangazu group.
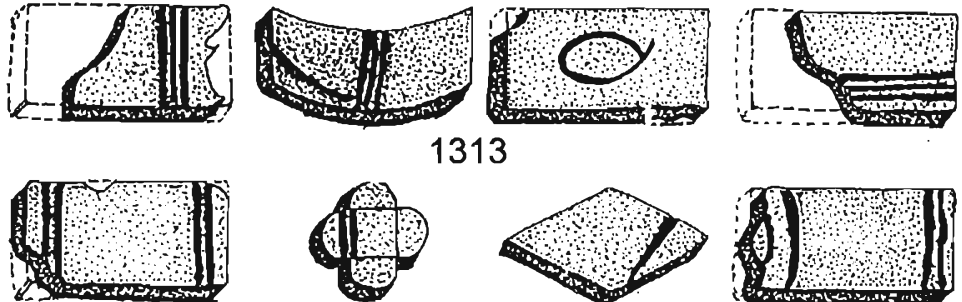

1313
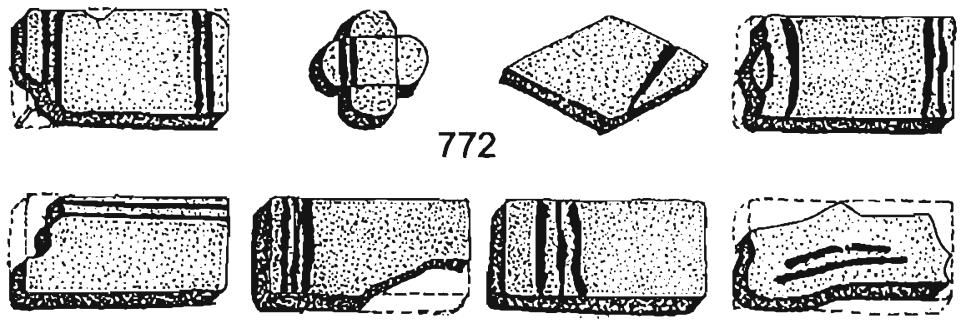

772

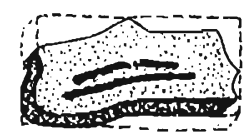

1179
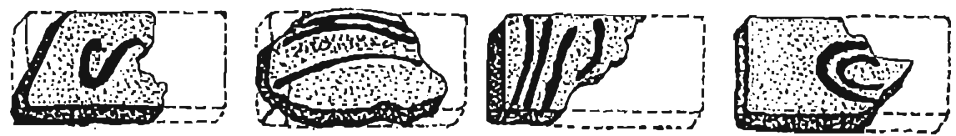

1224

Fig. 12. Pyu bricks found at Bagan, by Inventory number.

at the time to seek Pyu material at Bagan, would have been familiar with it from their excavations at Thayekittaya. Bronze Buddha images, reliefs and votive tablets of Maitreya, the Buddha of the future eras, have been found in relic chambers at Bagan (see Luce 1969, pl. 443-444), in some instances inscribed in Pyu script. Gutman (1996) suggests that these characteristically Pyu artifacts may represent a Messianic-type cult that emerged in Thayekittaya and was continued, possibly by Pyu residents or artisans, at Bagan. All this suggests a long-term presence of members of a group with "Pyu" skills and cultural products.

\section{CONCLUSION}

The notion that the Pyu were early inhabitants of Bagan is not new. Its mythological content aside, the foundation story related in the Glass Palace Chronicle 


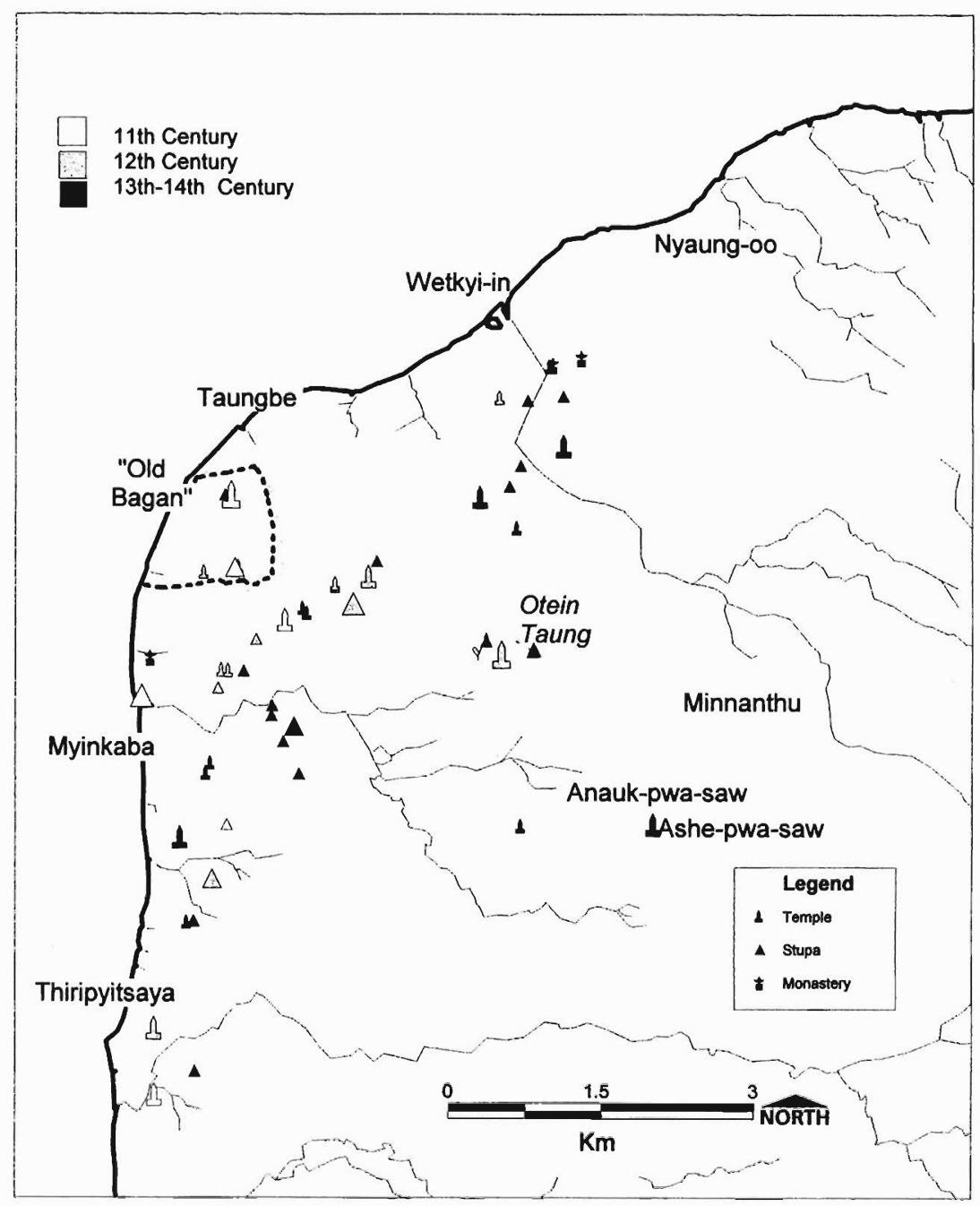

Fig. 13. Distribution of Pyu-style fingermarked brick in the monuments at Bagan.

(Pe Maung Tin and Luce 1923:28-45) is essentially one of settlement by Pyu groups migrating to the Bagan area amid regional conflict. The radiocarbon results now indicate that the antiquity of settlement activity at Bagan may be greater than is indicated by the inscription-based historical evidence. Spatial and archaeological evidence also suggests that by the eleventh century the Pyu, identified by their characteristic brick-making behavior, were sufficiently established in the area from the Wetkyi-in stream to Thiripyitsaya, and east to Otein Taung and beyond, to be represented in the fabric of buildings throughout this zone (Fig. 13). The restriction of Pyu bricks in buildings constructed between the eleventh and fourteenth centuries to certain areas of the overall monument zone might also suggest that the Pyu may have been excluded for some reason from donating building materials in Nyaung-oo, Taungbe, and the thirteenth-century monastic zone of Minnanthu. Further discoveries of Pyu bricks more widely over 
the city would weaken this particular hypothesis, but would strengthen the evidence of an overall Pyu presence.

McIntosh (1999:67) suggests that periods before the traditional dates for town or state formation are times of "spectacular dynamism, where extensive regions undergo rapid environmental and socio-political transformations." The Pyu appear to have transformed the landscape around their settlements in the dry zone of Upper Burma with irrigation, as exemplified by Stargardt (1990). Stresses relating to economic prosperity, population growth, or the physically limited space of the walled settlements may have sent groups out to experiment with new forms of living at Bagan, experiments that did not involve the inertia and resource commitment of huge walled settlements. Some of these people may have agglomerated from mid-eighth century or earlier on this bend of the Ayeyarwady, virtually equidistant from each of the northern walled Pyu centers. They may have dealt with the stress of relocation by clustering in ecosocially interdependent communities that left behind archaeological evidence such as pottery debris, bricks for the construction of religious buildings, and eventually, in the thirteenth century, complete religious structures that may have represented individual village residents.

The radiocarbon dates suggest that human settlement involving large amounts of pottery and fuel consumption was established at Otein Taung well before the historical period of the eleventh to thirteenth centuries. Evidence from the spread of Pyu bricks indicates that people who used distinctive fingermarks to tally or otherwise identify these artifacts were represented in the earliest dated buildings across much but not all of the city, including at Otein Taung. Spatio-temporal evidence from Bagan's key multi-attribute artifacts, its buildings, indicates that there may have been a number of long-term settlements spread throughout the urban complex.

Urban life in mid-first millennium Myanmar was largely characterized by the enclosed Pyu settlement. By the twelfth century A.D., it was characterized by a low-density, monument-rich complex that could expand without the constraint of a predefined outer boundary. The new evidence suggests that it is well worth seeking reasons for this dramatic change in human behavior in the early layers of the palimpsest of cultural deposits that is Bagan.

\section{ACKNOWLEDGMENTS}

This research was funded by the Carlyle Greenwell Bequest, the Australian Institute of Nuclear Science and Engineering (grant 00/180S), the James Kentley Memorial Scholarship, and a gift from Roma Wilson. It grew out of a MapInfo GIS (Geographical Information Systems) spatial analysis project, for which Pierre Pichard of the EFEO generously provided some of his then-unpublished data. In Myanmar, the work has been encouraged and facilitated by U Nyunt Han, Director General of Archaeology, and U Aung Kyaing, Assistant Director-General for Upper Myanmar, based at Bagan. Thanks for ongoing academic input is due to Roland Fletcher, Mike Barbetti, Michael Aung-Thwin, Miriam Stark, Andrew Wilson, Ian Johnston, and Pamela Gutman. In the field, we would like to acknowledge the contributions of Tessa Boermah, Emma Hetherington, Shah Alam Zaini, Don Tindale, Ted Robinson, Jordan Robinson, and our core crew of excavators, U San Ke, U Nyunt Aung, U Kan Myint, Bo Kyin, Aung-Nine, Shwe-oo, and Myint-oo. 


\section{NOTES}

1. The English romanization of Bagan for Pagan is used in this paper. It is appealing if only for the fact that it can no longer be confused by the lay person for the English word "pagan." Myanmar and Burma, the country's current and historical names, are used relative to the references in which those terms appear.

2. Map coordinates are quoted here in decimal degrees rather than degrees/minutes/seconds. This is the conventional form of longitude and latitude used in Geographical Information Systems (GIS) computer programs. The conversion formula is "decimal degrees = degrees + minutes/ $60+$ seconds/3600." Numbers used to identify buildings are from the Inventory of Monuments at Pagan.

3. The estimated commitment of building material to monument construction in Figure 1 , shown on the value (y) axis of the graph, is based on the relative volumes of dated buildings in the Inventory of Monuments. These have been extracted via the computer database of Pagan and Its Monasteries (Hudson 1997) in the proportion Small: Medium: Large: Very Large =1:8:40:400. We thank Pierre Pichard for allowing us to cite unpublished data that confirm this estimate is reasonable. The constantly updated Pagan and Its Monasteries database contains much of the tabular data from the Inventory of Monuments, with extra material such as metric eastings and northings of each monument that are based on the arbitrary "non-earth" grid used in the UNESCO mapping program at Bagan and our own survey data. Copies are available from the author.

4. Radiocarbon dates have been calibrated using cumulative probability, which is equivalent to a 2 -sigma range under the intercept method (Ramsey 2000). The dates and error for the OZE/F series were rounded before calibration.

5. The buildings at Bagan where Pyu bricks have been located by field survey and in some cases confirmed by the Inventory of Monuments at Pagan (Pichard 1992-1999) are numbers 265, 280, $286,289,292,306,320,329,348,420,421,772,797,804,805,808,812,813,820,894,996$, $1003,1029,1057,1058,1062,1086,1151,1179,1224,1232,1300,1304,1313,1317,1339$, $1344,1370,1372,1385,1387,1397,1469,1505,1519,1567,1601,1603,1611,1662,1663$, $1696,1697,1704$, and 1735 .

\section{REFERENCES CITED}

\section{Adhyatman, Sumarah}

1987 Kendi. Traditional Drinking Water Container Ceramic Society of Indonesia in cooperation with the Nusantara Jaya Foundation. P. T. Jayakarta: Agung Offset.

ASB (Archaeological Survey of Burma)

1901 - Report of the Superintendent, Archaeological Survey of Burma. Rangoon: Office of the Super-

1965 intendent, Government Printing. (Volumes from 1901-1905 titled Report on Archaeological Work in Burma.)

ASI (ARChaEOlogical Survey of INDia)

1902- Annual Report of the Archaeological Survey of India. Delhi: Manager of Publications.

1934

Aung Kyaing, U

1999 Ancient ceramic and glazed kilns at Bagan. Paper presented at Conference on glazed ceramics of South East Asia, Bagan. Myanmar, September 20-22.

Aung Myint

1999 Ancient Myanmar Cities in Aerial Photos. Yangon: Ministry of Culture (in Burmese).

Aung Myint, and Elizabeth Moore

1991 Finger-marked designs on ancient bricks in Myanmar. Journal of the Siam Society $72(2): 81-102$.

Aung Thaw

1968 Report on the Excavations at Beikthano. Rangoon: Revolutionary Government of the Union of Burma, Ministry of Union Culture.

1972 Historical Sites in Burma. Rangoon: Ministry of Union Culture.

Aung-Thwin, Michael

1985 Pagan: The Origins of Modern Burma. Honolulu: University of Hawai'i Press.

1994 Principles and patterns of the precolonial Burmese state, in Tradition and Modernity in Myanmar: 14-41, ed. Uta Gartner and Jens Lorenz. Berliner Asien-Afrika-Studien. 
1998 Myth and History in the Historiography of Early Burma. Athens: Ohio University Center for International Studies.

n.d. The Making of Modern Burma. Forthcoming.

Backus, Charles

1981 The Nan-chao Kingdom and T'ang China's Southwestern Frontier. Cambridge: Cambridge University Press.

Blagden, C. O.

1917 The "Pyu" inscriptions. Journal of the Burma Research Society 7(1):37-44.

CALLE

2001 Global Gazetteer. http://www.calle.com/world/index.html

Dello Strogolo, Sergio, and Kyaw Nyein

1963 Report on Pagan trip for analysis of old glazing kiln. Privately circulated mimeograph.

Di Crocco, Virginia

1990 Banbhore, an important river port on the ceramic and glass routes. Journal of the Siam Society 78(2): 79-89.

Donovan, D. G., Hayao Fukui, and Toshikatsu Itoh

1998 Perspective on the Pyu landscape. Southeast Asian Studies 36(1):19-126.

Duroiselle, Chas

1921 A List of Inscriptions in Burma. Rangoon: Superintendent of Government Printing, Burma.

FletCher, ROLAND

1995 The Limits of Settlement Growth. Cambridge: Cambridge University Press

Frasch, TILMAN

1996 An eminent Buddhist tradition: The Burmese Vinayadharas, in Traditions in Current Perspective: 115-144. Yangon: Universities Historical Research Centre.

Gutman, Pamela

1996 The Pyu Maitreyas, in Traditions in Current Perspective: 165-178. Yangon: Universities Historical Research Centre.

HeIN, Don

1996 Ceramic production in Myanmar-further evidence on old traditions, in Traditions in Current Perspective: 175-205. Yangon: Universities Historical Research Centre.

Hein, Don, Mike Barbetti, and Thongsa Sayavonghkamdy

1992 An Excavation at the Sisattanak Kiln Site, Vientiane, Lao PDR, 1989. Research Institute for Asia and the Pacific, University of Sydney.

Higham, Charles

1989 The Archaeology of Mainland South East Asia. Cambridge: Cambridge World Archaeology.

Hudson, BoB

1997 Pagan and Its Monasteries: Time, Space and Structure in Burma's Medieval Buddhist City. Unpublished B. A. (Honors) thesis, Archaeology Department, University of Sydney.

2000 The merits of rebuilding Bagan. Orientations 31(5) : 85-86.

2001 An Archaeological Settlement Database for Burma/Myanmar. Conference presentation: Towards an Electronic Cultural Atlas: e-publishing and Management in the Humanities, Sydney, June 12-13. http://www.archaeology.usyd.edu.au/ hudson/Burma_Myanmar_ database.pdf

Hudson, BOB, AND NyEIN LwIN

1999 Archaeological excavations and survey, February-March, 1999, Yon Hlut Kyun, Bagan, Myanmar: A preliminary report. Unpublished report to Director General of Archaeology, Yangon, Myanmar.

Hudson, Bob, Nyein Lwin, and “Tanpawady” Win Maung

2001 Digging for Myths-The Search for the Legendary 19 Founding Villages of Bagan. New Research in the Art and Archaeology of Burma. London: British Museum.

ISHIZAWA, YOSHIAKI

1989 Considerations regarding the basic framework of Pagan, 131-137. Study on Pagan Cultural Heritage in Asia 4. Tokyo: Institute of Asian Cultures, Sophia University. 
Kan HLA

1977 Pagan: Development and town planning. Journal of the Society of Architectural Historians $36(1): 15-29$.

Khin MAung NyunT

1989 The Role of Pagan in the History of Southeast Asia, 29-35. Study on Pagan Cultural Heritage in Asia 4. Tokyo: Institute of Asian Cultures, Sophia University.

1997 Hagiography of Maha Thera Shin Arahan and an Account of the Reconstruction of Shin Arahan's Brick Monastery. Myanmar: Ministry of Culture.

KHoo Joo Ee

1991 Kendi. Pouring Vessels in the University of Malaya Collection. Oxford: Oxford University Press.

LUCE, G. H.

1940 Economic life of the early Burman. Journal of the Burma Research Society 30(1):284-335.

1948 A century of progress in Burmese history and archaeology. Journal of the Burma Research Society 32(1) : 79-94.

1959 Geography of Burma under the Pagan dynasty. Journal of the Burma Research Society $42(1): 32-51$.

1961 (Translator) The Man Shu-Book of the Southern Barbarians. Data Paper 44, Southeast Asia Program, Cornell University.

1969 Old Burma-Early Pagan. Artibus Asiae and the Institute of Fine Arts, New York University (in three volumes).

MaUng HLa

1923 The chronological dates of the kings of Burma who reigned at Thayekhittaya (ancient Prome) and at Pagan. Journal of the Burma Research Society 13(2): 82-94.

Maung HTin Aung

1970 Burmese History before 1287: A Defence of the Chronicles. Oxford: The Asoka Society.

MCINTOSH, RODERICK J.

1991 Early urban clusters in China and Africa: The arbitration of social ambiguity. Journal of Field Archaeology 18:199-212.

1999 Clustered cities and alternative courses to authority in prehistory. Journal of East Asian Archaeology 1(1-4):63-86.

Ministry of Culture, Burma

1963 Pictorial Guide to Pagan. Rangoon: Ministry of Culture, Archaeology Department, Socialist Republic of the Union of Burma.

Moore, Elizabeth

1988 Notes on two types of moated settlement in northeast Thailand. Journal of the Siam Society $76: 275-283$.

Moore, Elizabeth, and Aung Myint

1993 Beads of Myanmar (Burma). Journal of the Siam Society 81(1):55-81.

MUdar, Karen M.

1999 How many Dvaravati kingdoms? Locational analysis of first millennium A.D. moated settlements in central Thailand. Journal of Anthropological Archaeology $18: 1-28$.

Myint Aung

1969 The contribution of libation jars to defining historical periods. Tetkatho Pyinnya Padetha $4(2): 35-46$ (in Burmese).

1970 The excavations at Halin. Journal of the Burma Research Society 53(2):55-62.

NIMA

2001 Burma Names File. US National Imagery and Mapping Agency. http://164.214.2.59/gns/ $\mathrm{html} / \mathrm{cntry}$ files.html

PARABAIK 495

n.d. The capsule summary regarding the glorious golden city of Bagan. Traditional manuscript in Burmese, in the collection of U Maung Maung Tin. English translation by $U$ Thaung Lwin.

Pe Maung Tin, and G. H. Luce (translators)

1923 The Glass Palace Chronicle of the Kings of Burma. Rangoon University Press. (Reprinted 1960). 
PICHARD, PiERRE

1992- Inventory of Monuments at Pagan, vols. 1-7: KISCADAle EFEO UNEsCo. (Vols: 1: 1992; 2:

1999 1993; 3, 4: 1994; 5: 1995; 6: 1996; 7: 1999.) Vol. 8: unpublished proofs supplied by the author. Copy retained at Rare Books Dept., Fisher Library, University of Sydney.

RAMSEy, Christopher Bronk

2000 OxCal Program v3.5. Radiocarbon Accelerator Unit, University of Oxford.

Reith, Charlotte

1997 Comparison of three pottery villages in Shan State, Burma. The Journal of Burma Studies $1: 45-82$.

ROONEY, DAWN

1999 New kiln finds in Cambodia and Myanmar (Burma). Lotus Leaves 3(1):4-6.

Sein Maung U

1981 Mongmao, a forgotten city. The Working People's Daily. 21 and 23 Jan., 3 Feb.

SIAM SOCIETY

1986 Thai Pottery and Ceramics: Collected Articles from the Journal of the Siam Society. Bangkok: The Siam Society.

STARgARDT, JANICE

1990 The Ancient Pyu of Burma: Early Pyu Cities in a Man-Made Landscape. Cambridge: PACSEA.

TAW SEIN KO

1895 Monograph on the Pottery and Glasstvare of Burma. GBCPO No. 5216.

Taw Sein Ko, and Chas Duroiselle, eds.

1919 Epigraphia Birmanica, Being Lithic and Other Inscriptions of Burma. Burma: Superintendent of Government Printing.

THAN TUN

1988 Essays on the History and Buddhism of Burma, ed. Paul Strachan. Kiscadale, Scotland.

1996 Defacing Old Bagan, in Bagan Lak Thit ("New Hand") and Other Essays, 182-204. Mandalay: Tun Yin Bookshop.

Thrn KYr, DAw

1964 The Old City of Pagan, in Essays Offered to G. H. Luce, vol. 2. Artibus Asiae.

Trigger, BRUCE

1990 Monumental architecture: A thermodynamic explanation of symbolic behaviour. World Archaeology 22(2): 119-129.

Universities Historical Research Centre

1996 Glimpses of Glorious Bagan. Yangon, Myanmar: The Universities Press.

Win Maung, U "Tanpawady"

n.d. Binnaka Myohaung ("Binnaka Ancient City"). In Burmese, privately circulated manuscript.

2000 Myittha eleven villages exploration record. In Burmese, paper read and privately circulated to commemorate the $84^{\text {th }}$ birthday of $U$ Maung Maung Tin. English translation by U Thaung Lwin.

\section{ABSTRACT}

Bagan is a major early urban center in Myanmar (Burma). Hundreds of Buddhist monuments were built there between the eleventh and thirteenth centuries A.D. The dating of activities earlier than this has until recently not been supported by scientific evidence. Part of Otein Taung, a "pottery hill" in the middle of the urban complex, has now been radiocarbon dated between A.D. 650 and 830 . A new survey of the spread of "Pyu" fingermarked bricks has located these cultural markers, widespread in Myanmar in the first millennium A.D., in more than 50 buildings at Bagan. This spatial and dating evidence suggests that before Bagan became a historically recorded economic and military power, and a key ritual center, it was a substantial settlement contemporaneous with some of Myanmar's distinctive first millennium "Pyu" sites. Keywords: Myanmar, Burma, Bagan, Pagan, archaeology, excavation, earthenware, pottery, Pyu, Tircul, urbanism, radiocarbon, settlement, spatial, GIS. 